\title{
Kajian Website Pendaftaran Peserta Pelatihan Pada Kemendag Dengan Pendekatan Technology Acceptance Model
}

\author{
Irawan Satriadi ${ }^{1}$, Amrin $^{2}$ \\ 1,2Fakultas Teknik dan Informatika Universitas Bina Sarana Informatika \\ e-mail: 1irawan.irs@bsi.ac.id, 2amrin.ain@bsi.ac.id
}

\begin{abstract}
Abstrak
Perdagangan dunia menunjukkan perkembangan dinamis terlebih dengan mulai diberlakukannya Free Trade Agreement. Hal ini perlu disikapi oleh para pelaku bisnis terutama eksportir dan calon eksportir, mengingat pasar internasional kini menuntut profesionalisme yang tinggi dan bukan sekedar transaksi. Dengan tuntutan tersebut, pelaku bisnis perlu memiliki keterampilan dan pengetahuan yang cukup untuk menangkap peluang serta memenuhi standar yang dikehendaki oleh pasar internasional. PPEI sebagai lembaga pendidikan dan pelatihan di bidang ekspor impor yang berada di lingkungan Direktorat Jenderal Pengembangan Ekspor Nasional Kementerian Perdagangan, senantiasa terlibat aktif dalam meningkatkan kemampuan sumber daya manusia para pelaku bisnis, dengan berbagai pengetahuan praktis dan keterampilan yang diperlukan untuk menjadi yang handal, berwawasan global dan berdaya saing tinggi. Penelitian ini bertujuan untuk mengevaluasi teknologi web dan mengetahui faktorfaktor yang dapat mempengaruhi penerimaan pengguna pada website pendaftaran peserta pelatihan di PPEI Kemendag. Hasil penelitian menunjukkan bahwa kemampuan diri calon peserta berinternet berpengaruh terhadap persepsi kemudahan calon peserta dalam menggunakan website, tidak berpengaruh terhadap niat untuk menggunakan website, dan tidak berpengaruh terhadap perilaku penggunaan website.
\end{abstract}

Kata kunci: Kajian website; ppei; training

\begin{abstract}
World trade shows dynamic development especially with the entry into force of the Free Trade Agreement. This needs to be addressed by business people, especially exporters and potential exporters, bearing in mind that international markets now demand high professionalism and not just transactions. With these demands, businesses need to have sufficient skills and knowledge to seize opportunities and meet the standards desired by the international market. PPEI as an educational and training institution in the field of export and import within the Directorate General of National Export Development Ministry of Trade, is always actively involved in improving the human resource capabilities of business people, with a variety of practical knowledge and skills needed to become reliable, global-minded. and highly competitive. This study aims to evaluate web technology and find out the factors that can influence user acceptance on the training participants registration website at the Ministry of Trade's PPEI. The results showed that the ability of potential online participants to influence the perception of the ease of potential participants in using the website, no effect on the intention to use the website, and no effect on website usage behavior.
\end{abstract}

Keywords: Review website; ppei; training

\section{Pendahuluan}

Perdagangan dunia menunjukkan perkembangan dinamis terlebih dengan mulai diberlakukannya Free Trade Agreement (FTA / Perjanjian Perdagangan Bebas) ASEAN-China tanggal 1 Januari 2010. Negara-negara ASEAN yang termasuk yaitu : Indonesia, Malaysia,
Singapura, Brunei, Vietnam, Filipina, Kamboja, Laos, Thailand dan Myanmar. Adapun hasil kesepakatan yaitu bea masuk produk manufaktur China ke ASEAN, termasuk Indonesia, ditetapkan di sektor pertanian nol persen tanpa pajak.

Sejalan dengan semakin ketatnya persaingan dalam merebut pasar, baik di 
tingkat lokal maupun mancanegara. Hal ini perlu disikapi oleh para pelaku bisnis (terutama eksportir dan calon eksportir), mengingat pasar internasional kini menuntut profesionalisme yang tinggi dan bukan sekedar transaksi. Dengan tuntutan tersebut, pelaku bisnis perlu memiliki keterampilan dan pengetahuan yang cukup untuk menangkap peluang serta memenuhi standar yang dikehendaki oleh pasar internasional.

PPEI sebagai lembaga pendidikan dan pelatihan di bidang ekspor impor yang berada di lingkungan Direktorat Jenderal Pengembangan Ekspor Nasional Kementerian Perdagangan, senantiasa terlibat aktif dalam meningkatkan kemampuan sumber daya manusia para pelaku bisnis, baik eksportir maupun calon eksportir dengan berbagai pengetahuan praktis dan keterampilan yang diperlukan untuk menjadi eksportir yang handal, berwawasan global dan berdaya saing tinggi. Penelitian ini bertujuan untuk mengetahui faktor-faktor yang dapat mempengaruhi penerimaan pengguna pada website pendaftaran peserta pelatihan di PPEI Kemendag.

Sebagai bahan acuan dan perbandingan, peneliti melakukan study literature pada beberapa penelitian sebelumnya. Diantaranya penelitian yang dilakukan oleh (Nurfiyah, Almira, Mayangky, Hadianti, \& Riana, 2019), yang berjudul Analisis Technology Acceptance Model Pada Aplikasi Platform Perdagangan Elektronik Di Kalangan Mahasiswa. Penelitian yang dilakukan (Napitupulu, 2017), dengan judul Kajian Penerimaan Elearning Dengan Pendekatan TAM. Penelitian yang dilakukan oleh (Hakim, 2017) yang berjudul Kajian Penerimaan Pengguna Terhadap Sistem CRM Di Perusahaan X Menggunakan Model TAM. Selanjutnya penelitian yang dilakukan oleh (Sayekti \& Putarta, 2016) yang berjudul Penerapan Technology Acceptance Model (TAM) Dalam Pengujian Model Penerimaan Sistem Informasi Keuangan Daerah. Penelitian yang dilakukan oleh (Agustian \& Syafari, 2014) yang berjudul Pendekatan Technology Acceptance Model ( TAM ) Untuk Mengidentifikasi Pemanfaatan Internet Usaha Kecil dan Menengah Sumatera Selatan. Terakhir penelitian yang dilakukan oleh (Siregar, 2011) yang berjudul Kajian Mengenai Penerimaan
Teknologi dan Informasi Menggunakan Technology.

\section{Metode Penelitian}

Jenis Penelitian yang akan dilakukan pada penelitian ini termasuk dalam kategori penelitian Explanatory, yaitu penelitian yang berisi pembuktian yang dibangun melalui teori dengan pendekatan Technology Acceptance Model (TAM), Setelah itu model diuji menggunakan salah satu perangkat lunak dalam hal ini AMOS (Santoso, 2007). Diharapkan dapat diidentifikasi faktor-faktor dominan apa yang saling berhubungan dan berpengaruh terhadap tingkat penerimaan tehnologi terhadap perilaku peserta pelatihan pada www.ppei.kemendag.go.id yang Berbasis Web sebagai sarana pendukung pada kementrian perdagangan Republik Indonesia khusunya PPEl.

Tabel 1. Indikator variable rutin

\begin{tabular}{|c|c|}
\hline Variabel Laten & Indikator \\
\hline $\begin{array}{l}\text { Internet Self } \\
\text { Efficacy (ISE) } \\
\text { Kemampuan } \\
\text { diri berinternet }\end{array}$ & $\begin{array}{l}\text {-Dapat mencari } \\
\text { yang dibutuhkan } \\
\text {-Dapat mendown } \\
\text { file dan menyimpan } \\
\text {-Dapat membuat } \\
\text { account baru } \\
\text {-Dapat } \\
\text { berkomunikasi } \\
\text { dengan chatt } \\
\text {-Dapat } \\
\text { berkomunikasi } \\
\text { dengan E-Mail }\end{array}$ \\
\hline $\begin{array}{l}\text { Perceived Easy } \\
\text { of Use (PEOU) } \\
\text { Kemudahan }\end{array}$ & $\begin{array}{l}\text {-Mudah diakses } \\
\text {-Mudah dipahami } \\
\text {-Mudah digunakan } \\
\text {-Mudah berinteraksi }\end{array}$ \\
\hline $\begin{array}{l}\text { Perceived } \\
\text { Usefulness } \\
\text { (PU) } \\
\text { Kemanfaatan }\end{array}$ & $\begin{array}{l}\text {-Mempertinggi } \\
\text { Efektifitas } \\
\text {-Menjawab } \\
\text { kebutuhan informasi } \\
\text {-Meningkatkan } \\
\text { pengetahuan } \\
\text {-Meningkatkan } \\
\text { efisiensi }\end{array}$ \\
\hline $\begin{array}{l}\text { Intention to } \\
\text { Use (ITU) } \\
\text { Niat } \\
\text { menggunakan }\end{array}$ & $\begin{array}{l}\text {-Penambahan } \\
\text { software pendukung } \\
\text { - Memotivasi tetap } \\
\text { menggunakan } \\
\text {-Memotivasi }\end{array}$ \\
\hline
\end{tabular}


JURNAL INFORMATIKA, Vol.7 No.1 April 2020

ISSN: 2355-6579 | E-ISSN: 2528-2247

\begin{tabular}{|l|l|}
\hline & pengguna lain \\
\hline WebsiteUsage & -Memahami cara \\
Behavior(WUB) & Menggunakan \\
Perilaku & -Menyampaikan \\
pengguna & kepuasan \\
& pengguna \\
& -Niat menggunakan \\
& 30 menit sehari \\
\hline
\end{tabular}

Structural Equation Model (SEM) adalah sekumpulan teknik-teknik statistika yang memungkinkan pengujian sebuah rangkaian hubungan secara simultan. Hubungan simultan ini dibangun antara satu atau beberapa variabel dependen dengan satu atau beberapa variabel independen.

Model structural adalah hubungan antara konstruk yang mempunyai hubungan causal (sebab akibat). Dengan demikian, akan ada variable independen dan variable dependen. Hal ini berbeda dengan model pengukuran (measurement) yang memberlakukan semua variable konstruk sebagai variable independen, namun berpedoman tetap pada hakekat SEM, semua kontruk dan hubungan antr konstruk harus mengacu pada dasar teori tertentu (theory - based).

faktor atau konstruk, yang dibangun dari beberapa variabel indikator.

$$
\begin{aligned}
& \mathrm{PEOU}=\gamma 11 \mathrm{ISE}+\varsigma 1 \\
& \mathrm{PU}=\beta 21 \mathrm{PeoU}+\gamma 21 \mathrm{ISE}+\varsigma^{2} \\
& \mathrm{ITU}=\beta 32 \mathrm{PU}+\beta 31 \mathrm{PEoU}+\gamma 31 \\
& \mathrm{ISE}+\varsigma^{3} \\
& \mathrm{WUB}=\beta 43 \mathrm{ITU}+\gamma 41 \mathrm{ISE}+\varsigma 4
\end{aligned}
$$

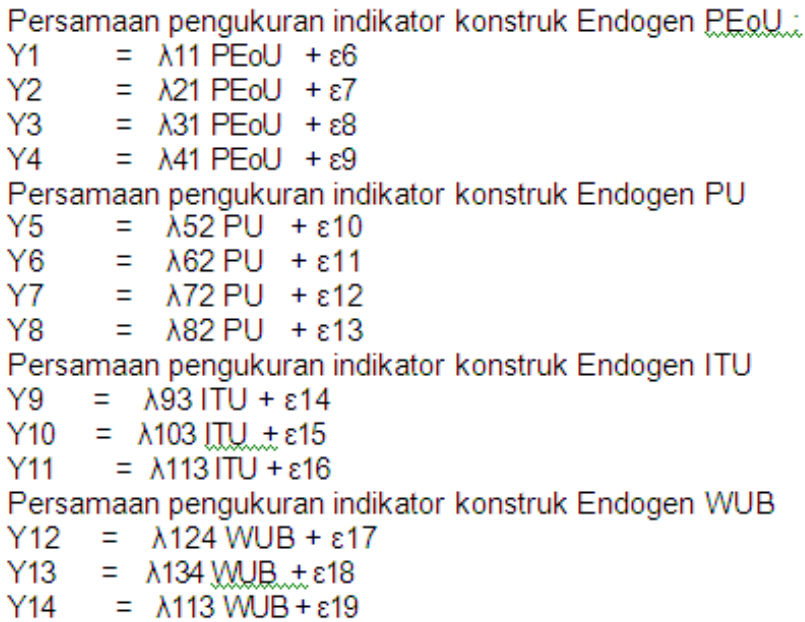

maka lika model dinyatakan cukup baik, melakukan interpretasi. Namun jika model dinyatakan belum baik atau tidak memenuhi syarat pengujian, maka perlu diadakan modifikasi. Setelah model diestimasi, residualnya haruslah kecil atau mendekati nol dan distribusi frekuensi dari kovarians residual harus bersifat simetrik.

\section{Hasil dan Pembahasan}

Responden yang mengembalikan kuesioner sebanyak 170 responden dari 200 kuesioner yang disebar. Kuesioner tersebut disebarkan secara langsung. Data yang valid untuk digunakan sebagai data penelitian sebanyak 170 kuesioner.

Dilihat dari profil responden penelitian pengguna WEB ppei.kemendag.go.id kebanyakan latar belakang pendidikan S1 $(57,6 \%)$, Jenis kelamin laki-laki $67,6 \%$, Usia 26-35 (35,8\%), Jenis Komputer yang digunakan PC windows $(57,6 \%)$, Broser yang digunakan mozila firefox $(62,4 \%)$, dan dengan Lama mengakses internet $<1$ jam $(81,2 \%)$. 


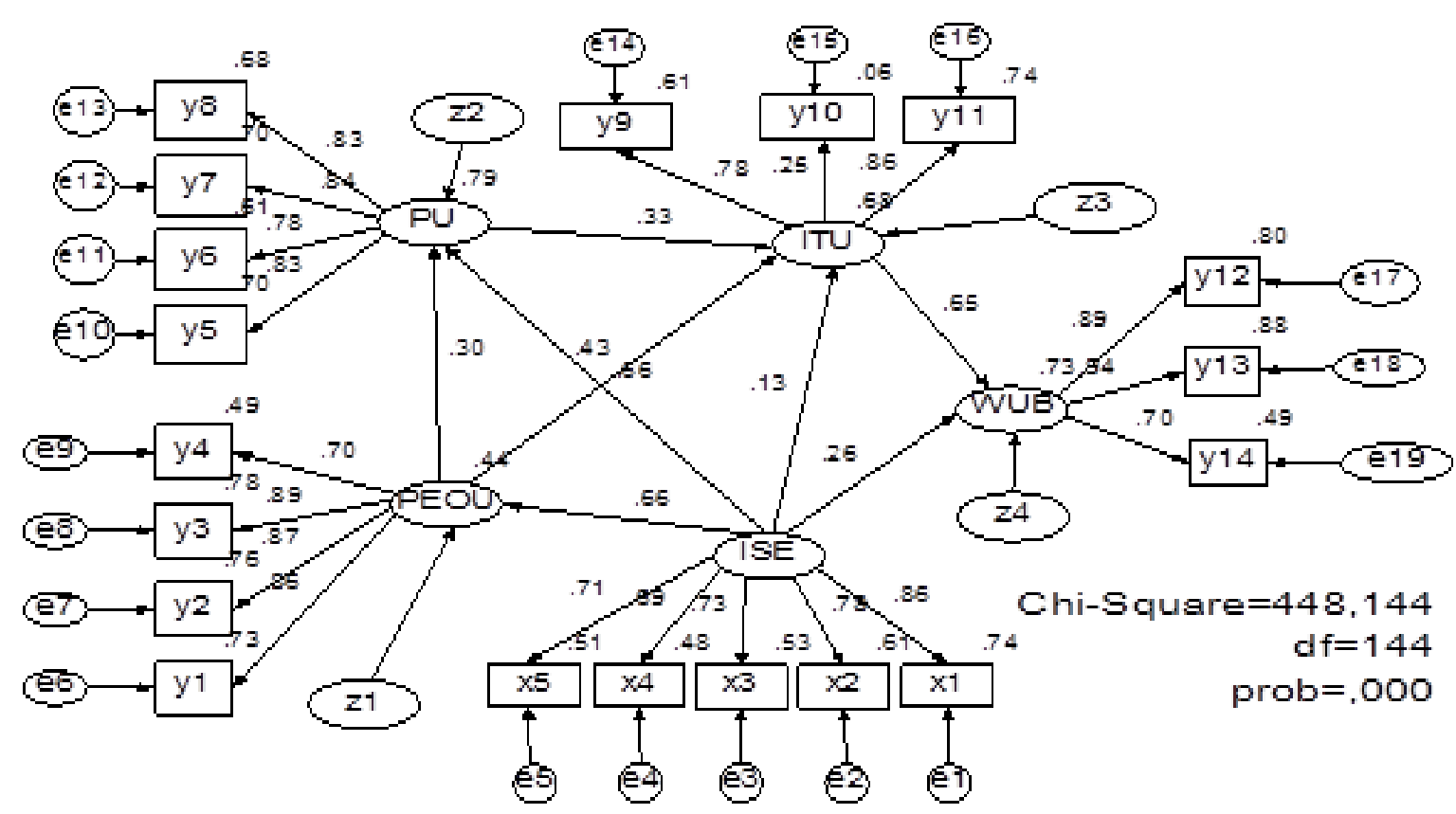

Gambar 1. Uji Measurement Model Awal Penelitian

Berdasarkan nilai signifikansi nilai semua variabel indikator diatas 0,5 (sign > 0.5 ), kecuali $\mathrm{Y} 10$ yang bernilai 0,25 yang jauh di bawah nilai 0,5 . Sehingga dapat dikatakan bahwa semua indikator berhubungan sangat signifikan dengan variabelnya, kecuali Y10 (Ghozali, 2008).
Assesment of Normality dapat dilihat secara univariate nilai critical skewness (kemencengan) sangat tinggi dan dapat disimpulkan data secara univariate tidak terdistribusi secara normal.

Tabel 2. Assesment of Normality Model Awal

\begin{tabular}{|l|llllll|}
\hline Variable & $\min$ & $\max$ & Skew & c.r. & kurtosis & c.r. \\
\hline x5 & 1,000 & 7,000 &,- 633 & $-3,368$ &, 693 & 1,845 \\
y10 & 1,500 & 58,000 & 11,643 & 61,976 & 143,508 & 381,941 \\
y14 & 1,000 & 7,000 &,- 552 & $-2,937$ &,- 070 &,- 187 \\
y13 & 1,500 & 7,000 &,- 279 & $-1,483$ &, 054 &, 144 \\
y12 & 1,500 & 7,000 &,- 310 & $-1,650$ &, 453 & 1,206 \\
y11 & 1,500 & 7,000 &,- 420 & $-2,235$ &, 329 &, 876 \\
y9 & 2,000 & 7,000 &,- 264 & $-1,406$ &,- 175 &,- 465 \\
y8 & 1,500 & 7,000 &,- 240 & $-1,280$ &,- 185 &,- 492 \\
y7 & 1,500 & 7,000 &,- 589 & $-3,137$ &, 727 & 1,936 \\
y6 & 1,500 & 7,000 &,- 403 & $-2,143$ &, 294 &, 783 \\
y5 & 2,500 & 7,000 &,- 121 &,- 642 &,- 671 & $-1,787$ \\
y4 & 2,500 & 7,000 &,- 085 &,- 450 &,- 377 & $-1,004$ \\
y3 & 3,000 & 7,000 &, 090 &, 481 &,- 661 & $-1,758$ \\
y2 & 2,500 & 7,000 &,- 208 & $-1,107$ &,- 335 &,- 891 \\
y1 & 3,000 & 7,000 &,- 309 & $-1,646$ &,- 717 & $-1,908$ \\
x4 & 1,000 & 7,000 &,- 325 & $-1,731$ &,- 389 & $-1,035$ \\
x3 & 1,000 & 7,000 &,- 199 & $-1,062$ &, 178 &, 475 \\
x2 & 1,500 & 7,000 &, 086 &, 456 &,- 231 &,- 615 \\
x1 & 1,500 & 7,000 &,- 305 & $-1,625$ &, 197 &, 525 \\
Multivariate & & & & & 305,078 & 70,405 \\
\hline
\end{tabular}


Berdasarkan (Mahalanobis distance) terdapat P1 atau P2 dibawah 0.05 yaitu pada data

ke $11,17,73,57,77,58,31,6,45,102,3,76,80,46$, 75,50 dan 38 karena itu dilakukan penghapusan terhadap data data tersebut sehingga jumlah data tersisa sebanyak 153 dan setelah dilakukan dengan pengujian dengan software AMOS maka didapat nilai multivariate Assesment of Normality menjadi 2,497 (standar nilai antara -2,582 sampai dengan $+2,582$ ) Oleh karena itu dapat dikatakan bahwa data terdistribusi secara normal, berarti data memenuhi syarat untuk dilakukan analisis selanjutnya. .Langkah selanjutnya melakukan modifikasi model dengan cara melakukan modifikasi error .

Sebuah model SEM yang komplek dengan banyak parameter yang harus di estimasi memerlukan jumlah sampel yang besar untuk dapat menghasilkan estimasi yang reliable. Sementara itu dengan jumlah sampel yang kecil akan selalu diperoleh hasil yang tidak memadai karena adanya varian yang negative (Heywood case) dan non-convergen solution (AMOS tidak mampu menyelesaikan estimasi).

Persoalan muncul apabila kita mempunyai model yang cukup komplek dengan melibatkan banyak indikator, sedangkan jumlah sampel yang ada tidak mencukupi untuk mengestimasi model komplek tersebut. Salah satu cara mengatasi hal ini adalah mengestimasi model SEM dengan indikator tunggal Komposite. Indikator tunggal komposit adalah menyederhanakan variable laten dengan multiple indikator menjadi hanya dengan satu indikator komposit tentunya yang dibenarkan secara teoritis atau empiris.

Dengan indikator tunggal komposite, maka model yang komplek tadi dapat dikurangi jumlah parameter yang akan diestimasi. Praktek yang banyak di lakukan dalam membuat indikator komposit hanya sekedar menjumlahkan masing masing skor indikator menjadi nilai total. Total nilai ini yang digunakan sebagai indikator tunggal. Cara menyusun indikator tunggal seperti ini tidak dapat dibenerkan secara teori, karena tidak mempertimbangkan bobot loading factor (score weight). Disamping itu penggunaan indikator komposit dapat dibenarkan jika kita mempertimbangkan nilai estimasi reliabilitas dan kesalahan pengukuran.
Dari dua tahap melakukan modifikasi terhadap model ternyata nilai Chi-Square masih bernilai 185,688, df bernilai 110 serta probality masih nol masih jauh di bawah 0,05 , sehingga model masih dianggap belum fit. Dikarenakan model sudah begitu komplek sedangkan nilai probability masih nol maka model dianggap tidak mewakili hasil secara populasi, sedangkan bila melihat good of fit atau Hasil lengkap pengukuran model penelitian rata rata nilai mendekati fit atau sudah fit, maka dapat disimpulkan bahwa model sudah fit untuk sampel dan bukan populasi;

Merubah model struktural dengan multiple indikator mejadi model komposite indicator. Model memiliki goodness fit yang baik dengan Chi-Sqare $=1,862$ dan probabilitas tidak signifikan 0,394. jadi model sesuai dengan data empirisnya.kriteria goodness fit yang lain GFI, AGFI, TLI dan RMSEA semua memenuhi criteria goodness fit .

Berdasarkan regression weights indikator terdapat hubungan yang tidak signifikan antara ISE ke ITU dengan nilai 0,085 dengan nilai estimasi 0,210 , serta hubungan antara ISE ke WUB sebesar 0,517 dengan nilai estimasi 0,063 , pada hubungan ini boleh dilakukan penghapusan tetapi boleh tidak dilakukan, antara variabel variable tersebut ada hubungan tetapi lemah.

\section{Kesimpulan}

Berdasarkan penjelasan sebelumnya, maka penulis menyimpulkan, yang pertama bahwa Internet Self Efficacy (ISE) atau kemampuan diri calon peserta berinternet berpengaruh terhadap Perceived Ease of Use (PEoU) atau persepsi kemudahan calon peserta dalam menggunakan website pendaftaran. Yang kedua bahwa Internet Self Efficacy (ISE) atau kemampuan calon peserta berinternet tidak berpengaruh terhadap Intention to Use (ITU) atau niat untuk menggunakan website pendaftaran. Yang ketiga bahwa Internet Self Efficacy (ISE) atau kemampuan calon peserta berinternet tidak berpengaruh terhadap Website Usesage Behavior (WUB) atau perilaku penggunaan website.

\section{Referensi}

Agustian, W., \& Syafari, R. (2014). Pendekatan Technology Acceptance Model ( TAM ) Untuk Mengidentifikasi 
Pemanfaatan Internet Usaha Kecil dan Menengah Sumatera Selatan. Seminar Nasional Teknologi Informasi \& Komunikasi Terapan 2014 (Semantik 2014), 20-25. Semarang.

Ghozali, I. (2008). Model persamaan structural, Konsep dan Aplikasi dengan program AMOS 16.0. Semarang: Badan Penerbit Universitas Diponegoro.

Hakim, M. M. (2017). Kajian Penerimaan Pengguna Terhadap Sistem CRM Di Perusahaan X Menggunakan Model TAM. Jurnal Teknologi Informasi Dan IImu Komputer, 5(1), 114-120. https://doi.org/10.25126/jtiik.20185156 3

Napitupulu, D. (2017). Kajian Penerimaan e-Learning Dengan Pendekatan TAM. Prosiding Seminar Nasional Multidsisiplin IImu Universitas Budi Luhur, 41-48. Jaka.
Nurfiyah, N., Almira, N., Mayangky, M., Hadianti, S., \& Riana, D. (2019). Analisis Technology Acceptance Model Pada Aplikasi Platform Perdagangan Elektronik Di Kalangan Mahasiswa. Jurnal Teknik Informatika, 12(1), 59-68.

Santoso, S. (2007). Structural Equation Modelling, Konsep dan Aplikasi dengan AMOS. Jogyakarta: Elex Media Komputindo.

Sayekti, F., \& Putarta, P. (2016). Penerapan Technology Acceptance Model (TAM) Dalam Pengujian Model Penerimaan Sistem Informasi Keuangan Daerah. Jurnal Manajemen Teori Dan Terapan, 9(3), 196-209.

Siregar, K. R. (2011). Kajian Mengenai Penerimaan Teknologi dan Informasi Menggunakan Technology. Jurnal Rekayasa, 4(1), 27-32. 